\title{
The Eggs and Larvæ of Turritella communis Lamarck and Aporrhais pes-pelicani (L.).
}

\author{
By \\ Marie V. Lebour, D.Sc., \\ Naturalist at the Plymouth Laboratory.
}

With Plates 1-2.

Nothing is known of the eggs and larvæ of Turritella communis and, except for the young shells which have already metamorphosed, those of Aporrhais pes-pelicani are also unknown. The following descriptions are therefore new, both molluses having been kept in plunger-jars until they laid their eggs.

\section{Turritella communis Lamarck.}

(Plate 1.)

Turritella communis is dredged alive in abundance in certain localities round Plymouth on muddy and sandy gravel, 15-30 fathoms or, rarely in over 40 fathoms (see Plymouth Marine Fauna, 1931, Marine Biological Association). Many were kept alive in plunger-jars, but, although they lived for a long time, feeding on detritus accumulating on the glass sides, no eggs were obtained for several months. At last, in May, some eggs were deposited in one of the jars, and after that several lots were laid up to August. Occasionally detached egg capsules were found in the plankton. Ripe sperm and nearly ripe eggs were found in November and February in a few individuals. I am indebted to Miss M. Rothschild and Mr. Idris Jones for records of much ripe sperm and ripe eggs in April, and very few in September. Apparently April to July is the natural breeding season as after June most of the eggs were shed.

Three egg-masses were found in a plunger-jar, 12.5.32. Each of these was a large cluster of capsules measuring from 6 to $10 \mathrm{~mm}$. across of a pinkish brown colour, sometimes rather yellowish when seen in a mass, the opaque eggs showing through the transparent capsules as small pink dots. The clusters have a peculiar lumpy appearance unlike the usual mollusc eggs. The capsules are held together by stalks, each capsule being roundish, oval and thick-walled, measuring about $0.64 \mathrm{~mm}$. to $1.12 \mathrm{~mm}$. across, those of the smaller diameter being the younger, the wall stretches as the eggs develop and becomes much thinner walled (Plate 1, NEW SERIES.-VOL. XVII. NO. 2. JANUARY, 1933. 
PLATE 1.

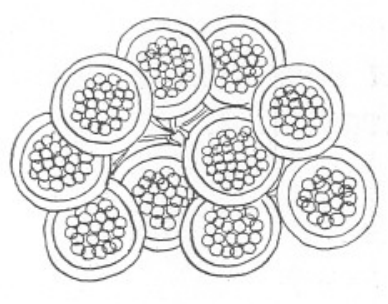

I
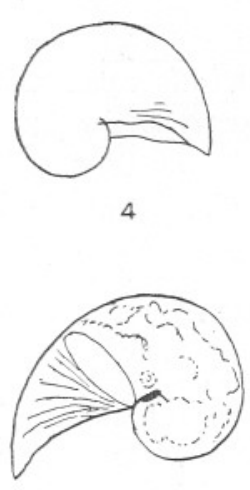

6

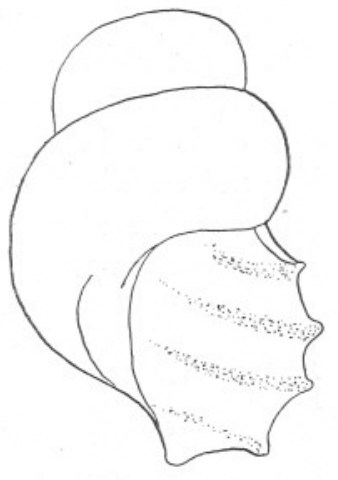

9

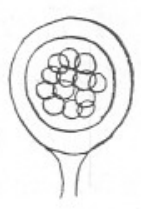

2

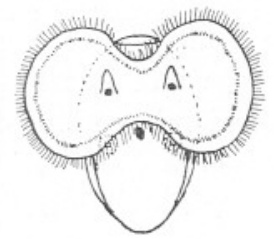

5

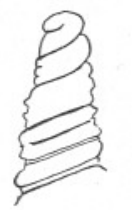

10

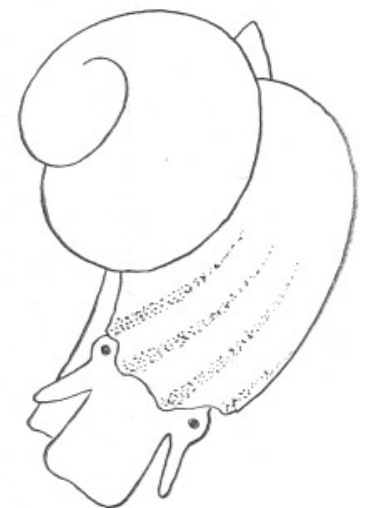

8
3

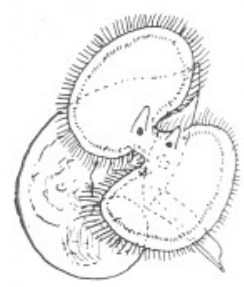

7 (e) ${ }_{0} 8$

O 
Figs. 1-3). Each egg when newly laid measures about $0 \cdot 10 \mathrm{~mm}$. across. and they lie at first closely packed together in the centre of the capsule with a space between them and the capsule wall, afterwards as they develop they are scattered about fairly far away from one another. There are from about 6 to 20 eggs or even more in each capsule and some hundreds of capsules in each egg-mass.

The eggs take about a week or ten days to hatch, but they are moving in the capsules with a well-formed velum a few days before this. Normally all the eggs develop and none of them devours its neighbour. The newly hatched larva is colourless, the shell consisting of one whorl, transparent and without sculpture, the shell measuring about $0.16 \mathrm{~mm}$. across. The outer lip is hardly drawn out into a tooth, the eyes and otocysts are conspicuous, the tentacles short and blunt, the velum about $0.18 \mathrm{~mm}$. across and perfectly colourless with the usual cilia bordering a groove to the mouth (Plate 1, Figs. 4-5). The larva has no special characteristics and resembles many other gastropod veligers, the simple outer lip being hardly in-curved indicating a short larval life as probably the velum will not be. large. As the second whorl grows the blunt characteristic apex is in: evidence. These larvæ only grew very little, the shell reaching a breadth of $0.18 \mathrm{~mm}$., and then they died (Plate 1, Figs. 6-7). It seems evident that they stay only for a short time swimming in the plankton and the shape of the velum probably does not change. No later larvæ were found in the plankton except one from the Mewstone Grounds which had already lost the velum, 4.7 .32 , although it only measured $0.48 \mathrm{~mm}$. in length (Plate 1, Figs. 8-9). The shell had two and a half whorls with a large apex - very large for the size of the shell-and sculptureless except for the last part of the second whorl which begins to have spiral ridges sculptured with fine dots. This is the beginning of the adult sculpture. The larva would thus begin to crawl with only about two to two and a quarter whorls, and would probably be very young, two or three weeks at the most. This crawling stage had an oblong proboscis, the tentacles

\section{EXPLANATION OF PLATE 1.}

(Scale B is six times the scale of A.)

Turritella communis.

(Figs. 2, 3-10 Scale A, Figs. 4-9 Scale B, Fig. 1 on a smaller scale.)

FIG. 1.-Part of cluster of egg-capsules laid in plunger-jar.

FIG. 2.-Newly laid capsule, $0 \cdot 64 \mathrm{~mm}$. across.

Fig. 3.-Older capsule, $1 \cdot 2 \mathrm{~mm}$. across.

FIG. 4-5.-Newly hatched larva from egg, $0 \cdot 16 \mathrm{~mm}$. across.

Fig. 6-7.-Larva 4 days old, $0 \cdot 18 \mathrm{~mm}$. across.

Fig. 8-9.-Turritella from plankton, having lost the velum, shell $0.48 \mathrm{~mm}$. long.

FIG. 10.-Apex of half-grown Turritella. 
PLATE 2.
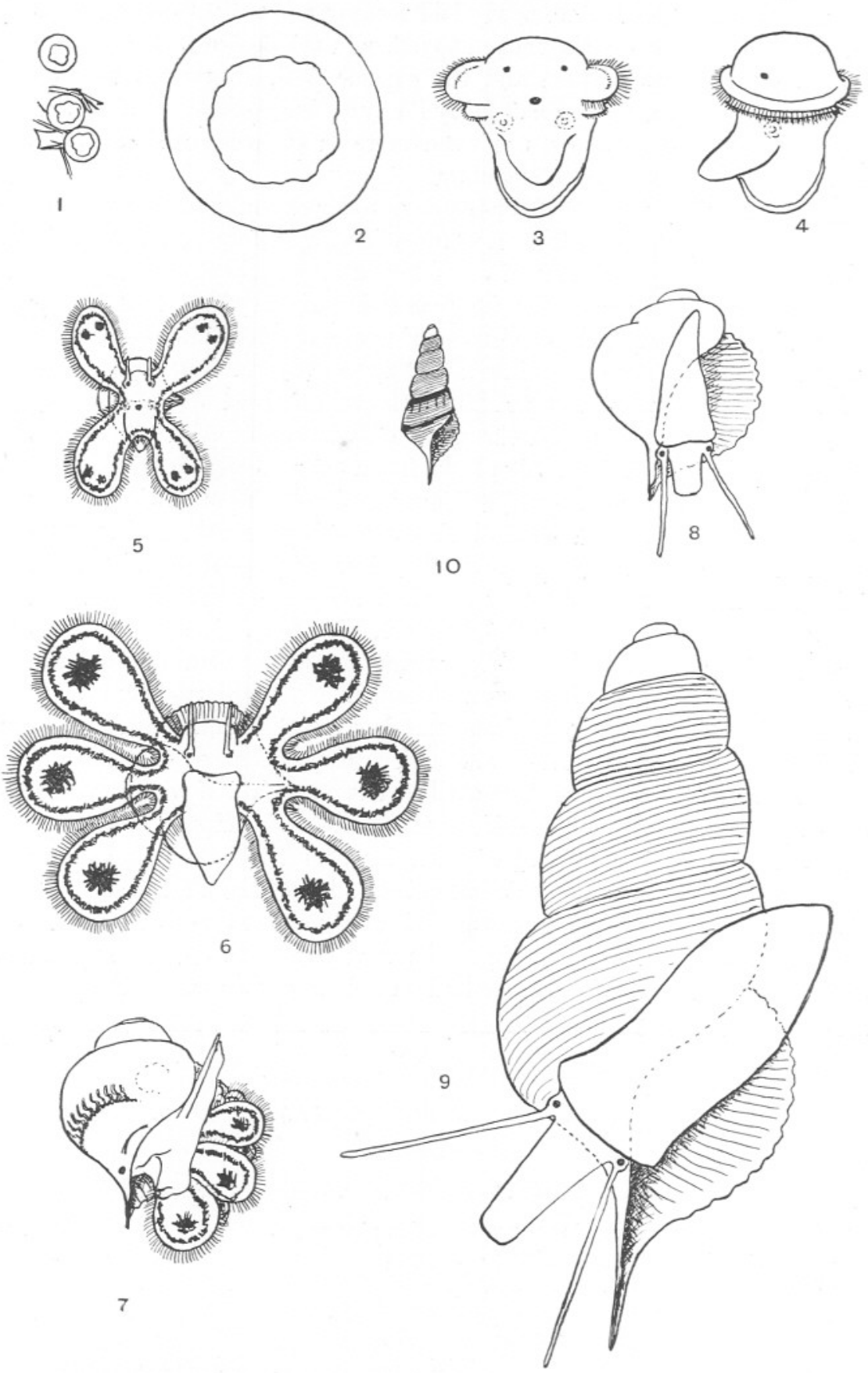
rather shorter than the proboscis, a short foot with a very contractile anterior portion. The body is pale yellowish, the shell a very pale brownish horn-colour. This tiny shell exactly corresponds with the apex of the older Turritella when that is intact (Plate 1, Fig. 10). Usually this tip is broken off in the adult shell. Except for the shorter tentacles and proboscis the young animal is very like the adult.

\section{Aporrhais PES-PELICANI (L.).}

\section{(Plate 2.)}

The young shells of Aporrhais pes-pelicani are known and have been described. Jeffreys (1867) gives an account of them, but apparently they have never been figured. The remainder of the life-history (eggs and free-swimming larvæ) is entirely unknown.

During the last few years whilst trying to unravel the problems of planktonic gastropod larvæ I have kept many molluses that they might lay their eggs. Amongst these were several specimens of Aporrhais pes-pelicani. It is not uncommon in the Plymouth waters, occurring occasionally both inside and outside the Sound, usually on muddy gravel in 5 to 35 fathoms. Six specimens, two of which were without the outer expanded lip and therefore young, were collected from Jennycliff Bay in the Sound and placed in a plunger-jar, January and March, 1932. Two of them were covered with growing red algæ. No food was given them, but apparently they found enough detritus to serve them as nourishment for they all flourished. Aporrhais is a detritus feeder, picking up with its long proboscis any small food from the sides and bottom of the plunger-jar.

On March 31st amongst the debris at the bottom of the jar consisting of

\section{EXPLANATION OF PLATE 2.}

(Scale B is six times the scale of A.)

Aporrhais pes-pelicani.

(Figs. 1, 5-9 Scale A, Figs. 2-4 Scale B, Fig. 10 on a smaller scale.)

Figs. 1, 2.-Eggs $0.25 \mathrm{~mm}$. across laid in plunger-jar.

Figs. 3-4.-Larvæ hatched from same, 0.24 mm. across.

Fig. 5.-Young larva from plankton (probably belonging to Aporrhais, $0.56 \mathrm{~mm}$. across shell).

Fig. 6.-Late larva from plankton, shell $1.25 \mathrm{~mm}$. long.

FIG. 7.-Late larva nearly ready to metamorphose, from plankton, shell $1.5 \mathrm{~mm}$. long.

FIG. 8.-The same, metamorphosed in plunger-jar.

Fig. 9.-The same, a month old, shell $5 \mathrm{~mm}$. long.

Fig. 10.-The same, $6.5 \mathrm{~mm}$. long. 
fine sand grains and mud, several eggs were found and these continued to be laid for some weeks. The eggs were transferred to a fresh plungerjar with Nitzschia, but although a few of them hatched out they did not live longer than a few days.

This is, I believe, the first time that the eggs of Aporrhais have been seen.

The eggs are unexpectedly small and laid singly, or two or three together, adhering to the sand and debris. The egg is spherical and measures about $0 \cdot 24 \mathrm{~mm}$. across (Plate 2, Figs. 1-2) with a thick tough coat, transparent and yellowish, with a good deal of fine dirt usually accumulated on its surface. The developing embryos inside measure about $0.12 \mathrm{~mm}$. across when spherical, but develop rapidly and soon become elongated. It was not possible to be sure of the length of time taken between laying and hatching as the eggs were all at different stages of development when found, probably a fortnight or so. From the egg came a very backwardly developed free-swimming larva, about $0.17 \mathrm{~mm}$. long, $0.16 \mathrm{~mm}$. at its widest near the velum. The larva is perfectly transparent and colourless with a short bilobed ciliated velum by means of which it moves, a large rounded protuberance in front, eyes without tentacles, otoliths, mouth and a short foot not reaching to the apex of the body. The shell itself is not yet formed. One or two long hairs project from the apex. These very backward larvæ soon died, none of them eating anything.

There is a gap in the life-history during the early larval life from the time of the formation of the shell to the late larval stages. The shelled early larva must have a fairly large shell, transparent and unsculptured. The velum changes from a bilobed to a six-lobed structure and must gradually acquire a brown spot at the end of each lobe. One larva was found in the plankton (Plate 2, Fig. 5) with a four-lobed velum, each lobe with two spots at the end, which probably was an Aporrhais, but as it did not live it was not possible to be certain of its identity. The shell of this larva was similar to the early portion of the late larva known to be Aporrhais. It is only when the velum is six-lobed that the larva is certainly identified. This occurs sparingly in the plankton in spring (May), both inside and outside the Sound. It is a very conspicuous and beautiful veliger (Plate 2, Fig. 6) with a shell of about three whorls, measuring $1.12 \mathrm{~mm}$. in length and about $1.0 \mathrm{~mm}$. in breadth. The upper whorls are clear and transparent without any sculpture, but the last half of the body whorl near the outer lip is distinctly striated transversely. There is no central process in the outer lip at this stage and the posterior end is pointed forming a very narrow siphon. The shell is a very pale yellowish horn colour. The animal is striking, having a smallish foot with a little brown pigment, pointed behind and produced into two blunt lobes in front covering the mouth which is also coloured brown, eyes at 
the base of long thin tentacles and between them the front produced in a broad lobe which will become the proboscis. The most conspicuous feature, however, is the velum which is large with six lobes, the whole stretch reaching for about $2 \cdot 8 \mathrm{~mm}$. The lobes have a narrow brown border, and at the end of each is a large brownish black spot. The whole has the usual outer border of longish cilia and a shorter border below, the two forming a groove to the mouth. As usual the shell is below the outstretched velum when swimming. This veliger, not very unlike that of the late larvæ of Nassarius incrassatus when the velum is retracted, can be distinguished by the broader apex and pointed siphon; when the velum is expanded the six lobes distinguish it at once.

Four of these late veligers were placed in a plunger-jar provided with Nitzschia. One of them, put in on May 11th, settled down almost at once and lost the velum, the shell in a day or two measuring $1.5 \mathrm{~mm}$. long. The foot had elongated slightly and lost the pigment, the tentacles were much longer and an oblong proboscis formed. This little shell was crawling about quite happily on the sides of the plunger-jar eating the debris very thinly accumulated on them. On May 31st it had grown to a length of $5 \mathrm{~mm}$. and was quite definitely a young Aporrhais. The proboscis was long and slightly tinged with red, the tentacles very long and waving. The shell has now five whorls, four of which form the somewhat cylindrical apex, the last being bulbous and coming out distinctly from the rest. The three last whorls are spirally striated and the pointed siphon is much longer. The siphon of the animal, which is very small, does not show at all. The shell now looks very like a Fusus or a Trophonopsis (Plate 1, Fig. 9). It grows very quickly, in two days having added another millimetre to its length. The little molluse of $6 \mathrm{~mm}$. crawls on the sides of the plunger-jar and can be seen to be eating the small masses of debris which cling to the glass in exactly the same way as the parents eat. At about $6.5 \mathrm{~mm}$., at about a month since its metamorphosis, the shell begins to have dark brown bands, one below the suture between the penultimate whorl and the body whorl and one round the periphery of the body whorl, the last being slightly keeled and having a faint indication of longitudinal ribs. As it gets older the shell is more distinctly coloured, but now its growth is much slower and for a second month it hardly grows half a millimetre although feeding well and moving about happily in the plunger-jar. It is still alive (August, 1932).

The other late larvæ died, but one collected a few days later metamorphosed in another plunger-jar but did not reach such a large size before it died. After May no larvæ were seen in the plankton. The spring months, especially April and early May, evidently being the time for them. 
A comparison with an Aporrhais, full-grown except for the outer lip, shows the top whorls to correspond exactly with the young one reared in the plunger-jar. Usually these top whorls are lost later and a shelly stopping covers the breakage.

\section{LITERATURE.}

Jeffreys, G. 1867. British Conchology, Vol. IV. 


\title{
The Eggs and Larvæ of Philbertia gracilis (Montagu).
}

\author{
By \\ Marie V. Lebour, D.Sc., \\ Naturalist at the Plymouth Laboratory.
}

With Plate 1.

THe genus Philbertia, belonging to the family Turridæ, is well known to have the larval shell beautifully sculptured and, as it is retained as the apex of the adult shell instead of being knocked off or concealed as is the case with many gastropods, it is easy to identify as belonging to this group, the veligers also reaching a large size and being conspicuous in the plankton.

Philbertia (Comarmondia) gracilis is fairly common in the Plymouth waters from 20-35 fathoms, usually in muddy ground, sometimes living with Turritella. Crawshay found one living from 40-42 fathoms S.W. of the Eddystone (see Plymouth Marine Fauna, 1931, Marine Biological Association). Its larvæ are quite common in small numbers in the plankton from inside and outside the Sound, usually outside, in spring and summer, the greatest number in the summer. It is one of the largest of the planktonic larval molluses, reaching a length of $1.76 \mathrm{~mm}$. or even more, and must stay for a long time in the plankton.

Jeffreys (1867) describes the apical whorls of this species (as Defrancia gracilis), although his description does not agree exactly with the Plymouth specimen, as he says that the top whorls are reticulated whereas they are really dotted and striated.

In the summer of 1931 two adult shells were placed in a plunger-jar where they lived quite comfortably, eating the deposits on the sides and bottom. In March of the following year seven capsules were laid on the side of the glass. Later, in April, another specimen was placed in the same jar which also laid several capsules of eggs. The eggs have not been seen before, and they and the larvæ are described here for the first time.

The capsules are very characteristic (Plate 1, Figs. 1-2), thick walled but fairly transparent, measuring $3.4 \mathrm{~mm}$. across, the height about onefifth of the diameter. The lower surface, attached to the glass, is flat, the upper raised portion reticulated with an irregular mesh raised into spiny processes. At the top is an oval depression covered by a much thinner skin through which the larvæ emerge. Each capsule contains about 